\section{SECOND RECORD OF RHINOLOPHUS BEDDOMEI IN EASTERN GHATS, INDIA}

\section{K. Thulsi Rao ${ }^{1}$, C. Srinivasulu ${ }^{2}$, R. Prudhvi Raj ${ }^{3}$, S.M.M. Javed ${ }^{4}$ and I. Siva Rama Krishna ${ }^{4}$}

${ }^{1}$ Assistant Conservator of Forests (Biodiversity), ${ }^{3}$ Field Director, Project Tiger, ${ }^{4}$ Field Research Assistant, ERM Laboratory, Nagarjunasagar Srisailam Tiger Reserve, Sunnipenta, Kurnool District, Andhra Pradesh 518102, India.

${ }^{2}$ (Corresponding author) Wildlife Biology Section, Department of Zoology, University College of Science, Osmania University, Hyderabad, Andhra Pradesh 500007, India.

2 Email: hyd2 masawa@sancharnet.in

with web supplement

Nallamala Hills $\left(14^{0} 26^{\prime}-16^{0} 31^{\prime} \mathrm{N} \& 78^{0} 30^{\prime}-80^{\circ} 10^{\prime} \mathrm{E}\right)$ is an unbroken chain of rugged hills running in north-south direction and encompassing an area of about $7,640 \mathrm{~km}^{2}$. Two protected areas, namely the Nagarjunasagar Srisailam Tiger Reserve $\left(3,568 \mathrm{~km}^{2}\right)$ and the Gundla Brahmeswaram Metta Wildlife Sanctuary $\left(1,194 \mathrm{~km}^{2}\right)$ located in the Nallamala Hills are home to diverse fauna (Srinivasulu \& Nagulu, 2002) including some rare taxon like Rusty-spotted Cat, Yellow-browed Bulbul, Little Pied Flycatcher and Yellow-throated Bulbul (Rao et al., 1999; Srinivasulu \& Rao, 2000; Srinivasulu, 2002, 2003). During one survey we collected one rare bat of the Eastern Ghats.

On 9 May 2002, around 1530h, we observed a bat hanging from the chain of the bell hung in the dome of an ancient Shiva temple $\left(15^{0} 39^{\prime} \mathrm{N} \& 7^{\circ} 43^{\prime} \mathrm{E}\right)$ on the Metta (=Plateau) (alt. $775 \mathrm{~m}$ ) in Gundla Brahmeswaram Metta Wildlife Sanctuary. The bat, a gravid female, was collected (Image $1^{\mathrm{w}}$ ) for identification and measurements (head and body length: $75.0 \mathrm{~mm}$; forearm length: $63.5 \mathrm{~mm}$; tail length: $44.0 \mathrm{~mm}$; hindfoot length: $16.0 \mathrm{~mm}$; and ear length; 29.0mm) during which it succumbed.

The specimen had conspicuous long and woolly pelage. Basing only on the external morphology, sella type (Image $2^{\mathrm{w}}$ ) and measurements, this species was identified to be the Lesser Woolly Horseshoe Bat, Rhinolophus beddomei (Chiroptera: Rhinolophidae). Cranial measurements were not taken because of lack of confidence in dissecting the single specimen. The specimen is wet preserved and deposited (Coll. No: ERM/ MC21) in the Field Museum of Andhra Pradesh Forest Department in the headquarters of Nagarjunasagar Srisailam Tiger Reserve at Sunnipenta, Kurnool District.

The ease of capture of this gravid female (by hand) could be because of her condition nearing parturition which indicates a later date than that reported by Brosset (1962) in March and April from Maharashtra. In Sri Lanka a gravid female was collected in January (Phillips, 1924) indicating a much earlier birthing season.

There is only one known locality, namely Thummalabailu ( $\left.14^{\circ} 11^{\prime} \mathrm{N} \& 79^{\circ} 09^{\prime} \mathrm{E}\right)$ Rajampeta Range, South Cuddapah, Andhra Pradesh in the Eastern Ghats from where this species was collected earlier in September 1929 (Paula Jenkins, in litt., 03
February 2003). The present collection is the second recorded occurrence of this species from the Eastern Ghats in Andhra Pradesh which increases its distribution range further north by about $160 \mathrm{~km}$.

\section{REFERENCES}

Brosset, A. (1962). The bats of central and western India. Part II. Journal of the Bombay Natural History Society 59: 583-624.

Phillips, W.W.A. (1924). A guide to the Mammals of Ceylon: Chiroptera. Spolia zeylanica 13: 1-63.

Rao, T.K., D. Sudhakar, V.V. Rao, V. Nagulu and C. Srinivasulu (1999). Rusty-spotted Cat Prionailurus rubiginosus (I. Geoffroy Saint-Hillaire, 1831): A new record for Nagarjunasagar Srisailam Tiger Reserve, Andhra Pradesh. Journal of the Bombay Natural History Society 96(3): 463-464.

Srinivasulu, C. (2002). Sight record of the Little Pied Flycatcher Ficedula westermanni Sharpe in Andhra Pradesh. Journal of the Bombay Natural History Society 99(3): 534.

Srinivasulu, C. (2003). Site records of Yellow-throated Bulbul Pycnonotus xantholaemus (Jerdon, 1844) in the Nallamala Hills, Eastern Ghats, Andhra Pradesh, India. Zoos 'Print Journal 18(3): 1051-1052.

Srinivasulu, C. and V. Nagulu (2002). Mammalian and avian diversity of the Nallamala Hills, Andhra Pradesh, India. Zoos'Print Journal 17(1): 675-684.

Srinivasulu, C. and V.V. Rao (2000). Occurrence of the Yellowthroated Bulbul Hypsipetes indicus (Jerdon) in the Nalamalla Hills, Andhra Pradesh. Journal of the Bombay Natural History Society 97(1): 144-145.

\section{ACKNOWLedgements}

We thank Mr. S.K. Das, IFS, PCCF, Mr. Hitesh Malhotra, IFS, Addl. PCCF (Wildlife) and Mr. A.V. Joseph, IFS, CCF (Wildlife) of Andhra Pradesh Forest Department for permission and encouragement. CS acknowledges Research Associateship grant by CSIR, New Delhi.

${ }^{w}$ See Images 1 \& 2 at www.zoosprint.org. 